\title{
HLA Genes in Afro-American Colombians (San Basilio de Palenque): The First Free Africans in America
}

\author{
Antonio Arnaiz-Villena ${ }^{*}, 1$, Raquel Reguera ${ }^{1}$, Carlos Parga-Lozano ${ }^{2}$, Sedeka Abd-El-Fatah-Khalil ${ }^{3}$, \\ Luis Monleon $^{3}$, Luz Barbolla ${ }^{3}$, Pablo Gomez-Prieto ${ }^{1}$, Jorge Martínez-Laso ${ }^{1}$ and Carlos Silvera ${ }^{4}$ \\ ${ }^{I}$ Department of Immunology, University Complutense, The Madrid Regional Blood Center, Madrid, Spain \\ ${ }^{2}$ Department Basic Science, Universidad del Sinú Seccional, Cartagena de Indias, Colombia \\ ${ }^{3}$ Department of Hematology, The Madrid Regional Blood Center, Madrid, Spain \\ ${ }^{4}$ Department of Genetics, Universidad del Norte, Barranquilla, Colombia
}

\begin{abstract}
An Afro-American semi-isolated Colombian population is studied for its HLA genes: San Basilio de Palenque community in Colombia northern mountains. This community represents the first free Africans in America earning recognition by the Spanish Crown in 1691 AD. Nowadays, they also speak the only extant Bantu-Spanish Creole language over the World; these people have been apart from there neighbours and claim a direct African descent. Their HLA genes were compared with African, Afro-American, Amerindian and worldwide populations by using genetic distances (DA), Neighbour-Joining dendograms and correspondences analyses. Arlequin, DISPAN and VISTA softwares were used for the completion of these computerised calculations. San Basilio de Palenque, a relatively ethnic isolate, is genetically close to other North and South Afro-Americans and to West Africa-Bantu speaking groups (Senegalese; Bubi, Guinea Gulf). Five HLA extended haplotypes are found only in this population: A*02-B*07-DRB1*0801-DQB1*0301, A*02-B*35DRB1*1304-DQB1*0301, A*02-B*15-DRB1*0302-DQB1*0402, A*01-B*51-DRB1*0301-DQB1*0201, A*68-B*15DRB $1 * 0102-\mathrm{DQB} 1 * 0501$. Only very limited gene flow is found from either Amerindians or Europeans, as expected by historical records. Our HLA data may also prove useful for future regional transplant programs and genetic epidemiology of HLA-linked diseases.
\end{abstract}

Keywords: First free Afro-Americans, Afro-Americans, HLA, Bantu-Spanish Creole, Creole, Colombia, transplantation, genetic epidemiology.

\section{INTRODUCTION}

The highly polymorphic HLA system has been validated as useful for distinguishing and/or relating populations and individuals. HLA gene frequencies correlate with geographically related populations; the existence or absence of gene flow among neighbours may be assessed with the study of HLA frequencies and the corresponding genetic distances. Certain alleles are frequent only in specific populations (i.e., A36, A43 in Afro-Americans) and the strong linkage disequilibrium between HLA neighbouring loci demonstrates that certain combinations of contiguous alleles (HLA haplotypes) show a characteristic frequency or are distinctive for certain living populations [1-3].

At present, Colombia has a complex ethnicity, which is mainly composed of Mestizo groups (58\%; Afro-Americans, Amerindians, European Caucasoids), European Caucasoids (20\%; White Europeans), Mulatto groups (14\%; AfroAmericans, European Caucasoids), Afro-Americans (4\%; Black Africans) and Amerindians (1\%). Pure Amerindians may be underestimated and included in the last group, because of recent rural to urban cities emigration [4]. The

*Address correspondence to this author at the Departamento de Inmunologia, Facultad de Medicina, Universidad Complutense, Pabellon 5, planta 4. Avda. Complutense s/n, 28040 Madrid, Spain; Tel: +34 913 941632; Fax: +34 9130173 56; E-mail: aarnaiz@med.ucm.es
Black Colombians are descendents of Black people who were brought to America by Spaniards from West African regions (i.e., Mali, Senegal and Guinea) in the beginning of the $16^{\text {th }}$ century $\mathrm{AD}[5]$. These African people are related to those Africans from the Guinea Gulf, who invaded and overwhelmed Central and South Africa by 400 years AD and reduced and cornered other ethnicities such as Bushmen and Pygmies: the Bantu expansion [6,7]. They belonged to several linguistic groups, principally the Bantu language (NigerCongo phylum). The strategic placement of Cartagena de Indias city at the North coast of Colombia was used to introduce African populations to work in agricultural fields (North coastal areas) and others were transferred to inner regions (South and Pacific coasts) to work in gold mines [5]. In $1599 \mathrm{AD}$, Black African slaves started to escape from coastal city Cartagena de Indias and took refuge in nearby Maria Mountains, establishing the first traces of San Basilio de Palenque city. After a tough fight with Spanish army, the Spanish Crown at Madrid issued a Royal Decree in 1691 $\mathrm{AD}$, guaranteeing freedom for Africans at San Basilio de Palenque; however, real African autonomy became possible here in $1713 \mathrm{AD}$ after intense agitation, becoming the first free African community in America [8]. Colombia reached independence from Spain in 1819 AD. However, several groups of these African descending groups started to organise themselves in small villages throughout Iberian America; these villages were called "Palenques" in Colombia, Cuba 
and Mexico. By the end of the $17^{\text {th }}$ century, escaped African slaves tried to keep their own African basis as well as their African cultural identity in these stronghold villages [5]. Nowadays, there are some old cities named "Palenques", distributed mainly in Cuba, Mexico and Colombia (Fig. 1), and in other parts of Iberian America with different names. On the other hand, these African descending populations have been living close to native Amerindian tribes and Caucasians for almost 500 years and possibly they may have received genetic flow and admixture from these neighbouring populations. Previous HLA genetic studies in other AfroAmerican groups, have revealed a high allelic diversity related with an African populations high genetic diversity [1] Moreover, specific alleles and HLA haplotypes have been reported specifically in several Black groups (i.e., HLA-A36, HLA-A43, HLA-B53, and DRB1*0804-DQB1*0301 disequilibrium), which highlights a specific genetic background for these Afro-American people [9-11].

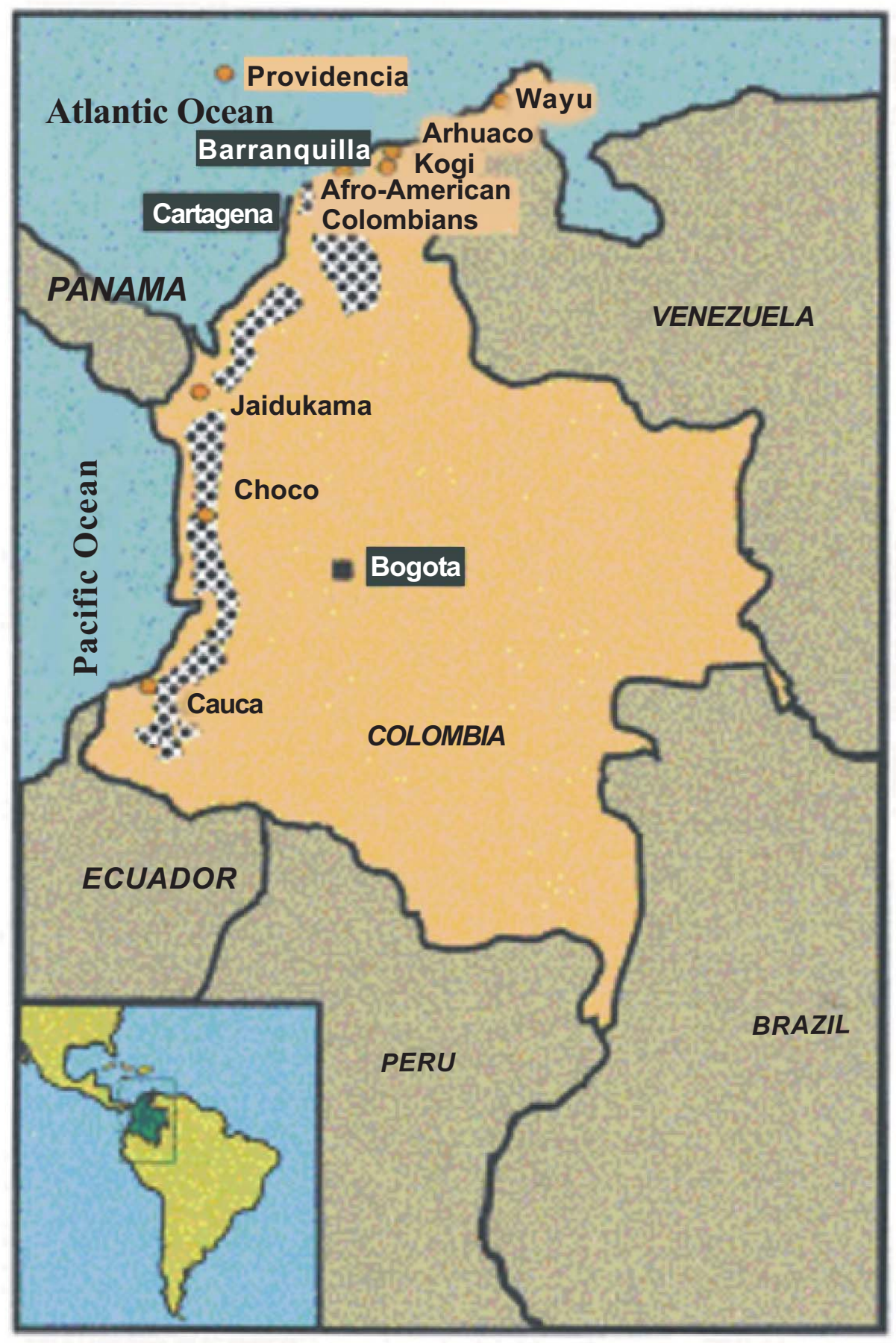

Fig. (1). Map showing the geographic location of the Afro-American Colombian population studied (San Basilio de Palenque, Bolívar Dept, close to Cartagena de Indias) and, other Afro-American Colombian groups (Providencia, Cauca and Choco) and some Amerindian groups (Wayu, Arhuaco, Kogi and Jaidukama). Dotted areas indicate localisation of Mulatto and Black African groups throughout coastal Colombia. Black names indicate countries. Black boxes with white letters indicate main cities. Providencia Island is located close to Nicroragua Coast in the Atlantic Ocean. 
In the present work, we have studied an Afro-American Colombian group (from San Basilio de Palenque) HLA profile and compared it with other African, Afro-American, Caucasian, Amerindian and worldwide populations. This particular group from San Basilio de Palenque (Bolivar Province, Colombia) is the first as regarded as AfroAmerican community recognised as "free" by the Spanish Kings [8] as gene flow from outside is doubtful since 1691$1713 \mathrm{AD}$; its mixed Creole Spanish-Bantu language is unique, since it is the only extant Spanish-Bantu Creole language over the Word [12]. Our aims in this study are: 1) To determine the HLA Class I (-A and -B) and Class II (DRB1 and DQB1) Afro-American Colombian alleles by using indirect DNA sequencing (reverse dot-blot methodology); 2) To compare this Afro-American Colombian group HLA profile with that of other worldwide populations in order to know their genetic relationship, particularly with other Africans and Afro-Americans, since San Basilio de Palenque population tested here seems to have received limited gene flow from other ethnic groups; and 3) To verify a possible gene flow and/or admixture with neighbouring Amerindian and Caucasoid groups.

\section{MATERIAL AND METHODS}

\section{Population Sample}

Forty-two healthy unrelated individuals from an AfroAmerican Colombian group were HLA class I and class II typed. These Afro-American people inhabit a classical Negroid village in the Caribbean coast of Colombia: San Basilio de Palenque, having approximately 3500 inhabitants (near Cartagena de Indias, Fig. (1)). They show Negroid phenotypes, typical of Negroid culture as well as a mostly African genetic pool suggested by characteristic pathologies like the sickle cell disease [13]. Each individual was born in this Afro-American area and their ancestors had directly originated from African people (Bantu tribes), brought by Spaniards to America as slaves. We also compared our data with those of Caucasian Europeans, Africans, AfroAmerican, Amerindian and other possibly related groups $[10,11]$, obtaining the corresponding genetic distances, relatedness dendrograms and correspondence analysis. In particular, we tried to include the main Negroid groups HLA results reported in literature for our genetic population analysis.

\section{HLA Genotyping and Statistics}

Generic HLA class I (A and B) and high resolution HLA class II (DRB1 and DQB1) was performed using a reverse dot-blot technique with the Automated Innolipa system (Innogenetics NY., Zwijndrecht, Belgium). HLA-A, -B, DRB1, and -DQB1 allele DNA sequencing was only done when indirect DNA typing yielded ambiguous results [14]. Statistical analysis was performed with Arlequin v2.0 software kindly provided by Schneider [15]. In summary, this program calculated HLA-A, -B, -DRB1, and -DQB1 allele frequencies, Hardy-Weinberg equilibrium and the linkage disequilibrium between two alleles at two different loci. Their level of significance (p) for $2 \times 2$ comparisons was determined as previously described [16]. In addition, the most frequent complete haplotypes were deduced from: 1) the 2, 3, and 4 HLA loci haplotype frequencies [16,17]; 2) the previously described haplotypes in other populations [16]; and 3) haplotypes if they appeared in two or more indi- viduals, with the alternative haplotype being well defined [16]. In order to compare phenotype and haplotype HLA frequencies with other populations, the reference tables of the $11^{\text {th }}$ and $12^{\text {th }}$ International HLA Workshops were used $[10,11]$. Phylogenetic trees (dendrograms) were constructed with the allelic frequencies using the Neighbour-Joining (NJ) method [18] with the genetic distances between populations (DA) [19], using DISPAN software, which comprises the programs GNKDST and TREEVIEW [20,21]. Correspondence analysis in three dimensions and its bidimensional representation was carried out using the VISTA v5.02 computer program ([22], http:/forrest.psych.unc.edu). Correspondence analysis consisted of a geometric technique that may be used for displaying a global view of the relationships among populations according to HLA (or other) allele frequencies. This methodology is based on the allelic frequency variance among populations (similar to the classical components methodology) and on a statistical visualisation of the differences.

\section{RESULTS}

\section{Characteristic HLA Allele Frequencies of the Afro- American Colombian Group Compared to Other Popula- tions}

The expected and observed gene frequency values for HLA-A, -B, -DRB1, -DQB1 loci did not differ significantly and the population was in Hardy-Weinberg equilibrium. Table 1 shows the HLA allele frequencies found in the AfroAmerican Colombian population of San Basilio de Palenque. Twelve different HLA-A and twenty-one different HLA-B alleles were found in the Afro-American Colombian group. However, only four HLA-A alleles and five HLA-B alleles had frequencies higher than $10 \%(A * 02, A * 23, A * 68, A * 74$, $\mathrm{B}^{*} 08, \mathrm{~B}^{*} 14, \mathrm{~B}^{*} 15, \mathrm{~B}^{*} 35$ and $\left.\mathrm{B} * 52\right)$. Frequencies of the HLA class II alleles ranged from $2.5 \%$ to $7.5 \%$, these included the allele groups DR1 (DRB1*0102), DR2 (DRB1*1501,*1503), DR3 (DRB1*0301,*0302), DR5 (DRB1*1101,*1102,*1104), DR6 (DRB1*1301,*1302, *1303, *1304, *1404), DR7 (DRB1*0701), DR8 (DRB1*0801, *0804), DR9 (DRB1*0901) and DR10 (DRB1*1001). In addition, other alleles such as DRB1*0403, DRB1*0411 and DRB1*1602 were found in a low frequency (1.2\%). DQ allele frequencies reflect the DRB1 locus allele distribution due to the strong linkage disequilibrium between these two loci (see haplotype data). Data reported in this study on HLA class I and class II polymorphism (high frequency of $A * 23, A * 68, A * 74, B * 08$, $\mathrm{B} * 15, \mathrm{~B} * 35, \mathrm{~B} * 52, \mathrm{DRB} 1 * 1501, \mathrm{DRB} 1 * 1503$, DRB1*1304, DRB1*0701, DRB1*0801 and DRB1*0804) are in agreement with those previously described in other AfroAmerican groups and other Negroid related populations [2326].

However, typical African and Afro-American alleles i.e., A36 was present in middle frequency (5\%) while A43 was not found. On the other hand, class I alleles such as B42, B45 were present in sub-Saharan people [27], North and West African populations [28], Southern Africans [29], North American and South American Negroids [30], Mulattos from Cartagena (Colombia) [23] and Colombian Blacks (from Pacific Coast) [31] with notable frequencies were not being found in this group. Moreover, Negroid HLA-B*5301 
Table 1. HLA-A, -B, -DRB1 and -DQB1 Allele Frequencies in the Studied Afro-American Colombian Population

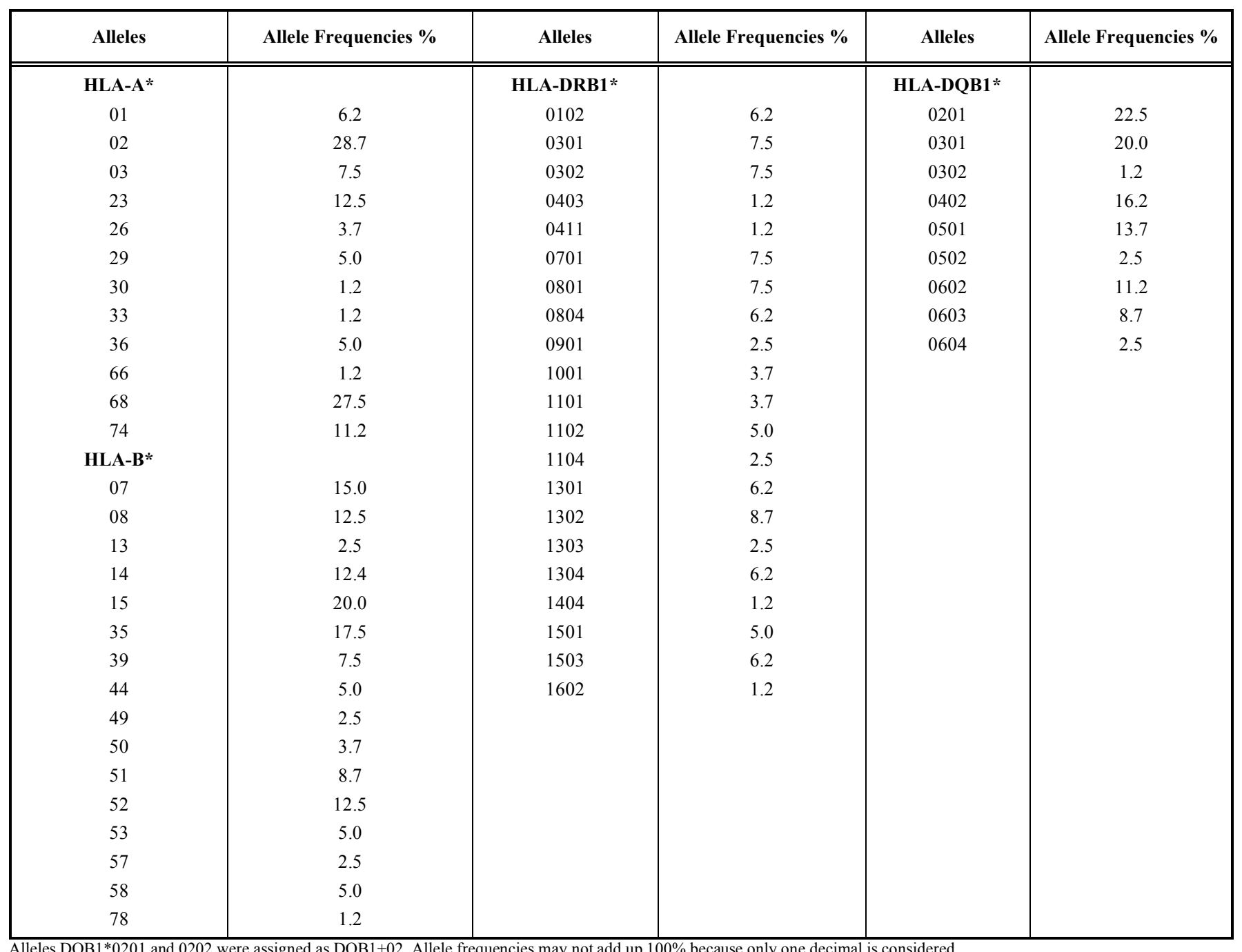

allele, which has been related with resistance to a severe form of Malaria in the Gambian population [32], was found in a middle frequency (5\%) in our Afro-American Colombian group compared with Colombian Blacks from one endemic Malaria area (15.2\%) [33].

Two types of analyses were done in order to compare Afro-American Colombian HLA frequencies with other World population frequencies: 1) with pooled DRB1 and DQB1 data; and 2) with DRB1 only, which is probably a more discriminating methodology. It was not possible to carry out a study comparing HLA class I allele frequencies or HLA class I and II conjointly mainly due to the lack of HLA Class I typing in several related groups, like Black people from Cauca, Providencia and Choco (Colombia) [24], and others like Afro-Americans from New York City, NYC [26]. DRB1 and DRB1-DQB1 study was carried out in order to compare our Afro-American Colombian HLA population frequencies with a great number of worldwide populations. Fig. (2) depicts an HLA-DRB1 neighbour-joining tree and shows how our Afro-American Colombian population was clustered together with other Negroid populations and was also close to Mediterranean populations; it is also seen in the correspondence analysis (Fig. 3). When we included DRB1-
DQB1 analysis, the topology of the tree did not change (results not shown). This effect is also evident when plain DA genetic distances are considered (not shown). In fact, the closest populations to our Afro-American Colombian group are the North American Blacks, followed by West African populations such as Senegalese and Bubis from Bioko Island (Gulf of Guinea). Mediterranean populations followed West African populations in genetic distances value (Black Africans and Mediterraneans share a quite similar HLA profile, [34]). Amerindians showed far genetic distances as compared to our San Basilio de Palenque group. This is reflected in the NJ dendrogram and correspondence analyses.

\section{HLA-A, -B, -DRB1 and DQB1 Linkage Disequilibria in Our Afro-American Colombian Group Sample Com- pared to Other Populations}

Associations between different HLA loci were estimated. The most probable two loci haplotype combinations (A-B, B-DRB1 and DRB1-DQB1) were calculated (Table 2). There were 15 haplotype frequencies of about $5-15 \%$ out of a total of 25 combinations found in high frequency. This haplotype study shows that the most common ones are predominantly found in both Negroid and Caucasoid- 


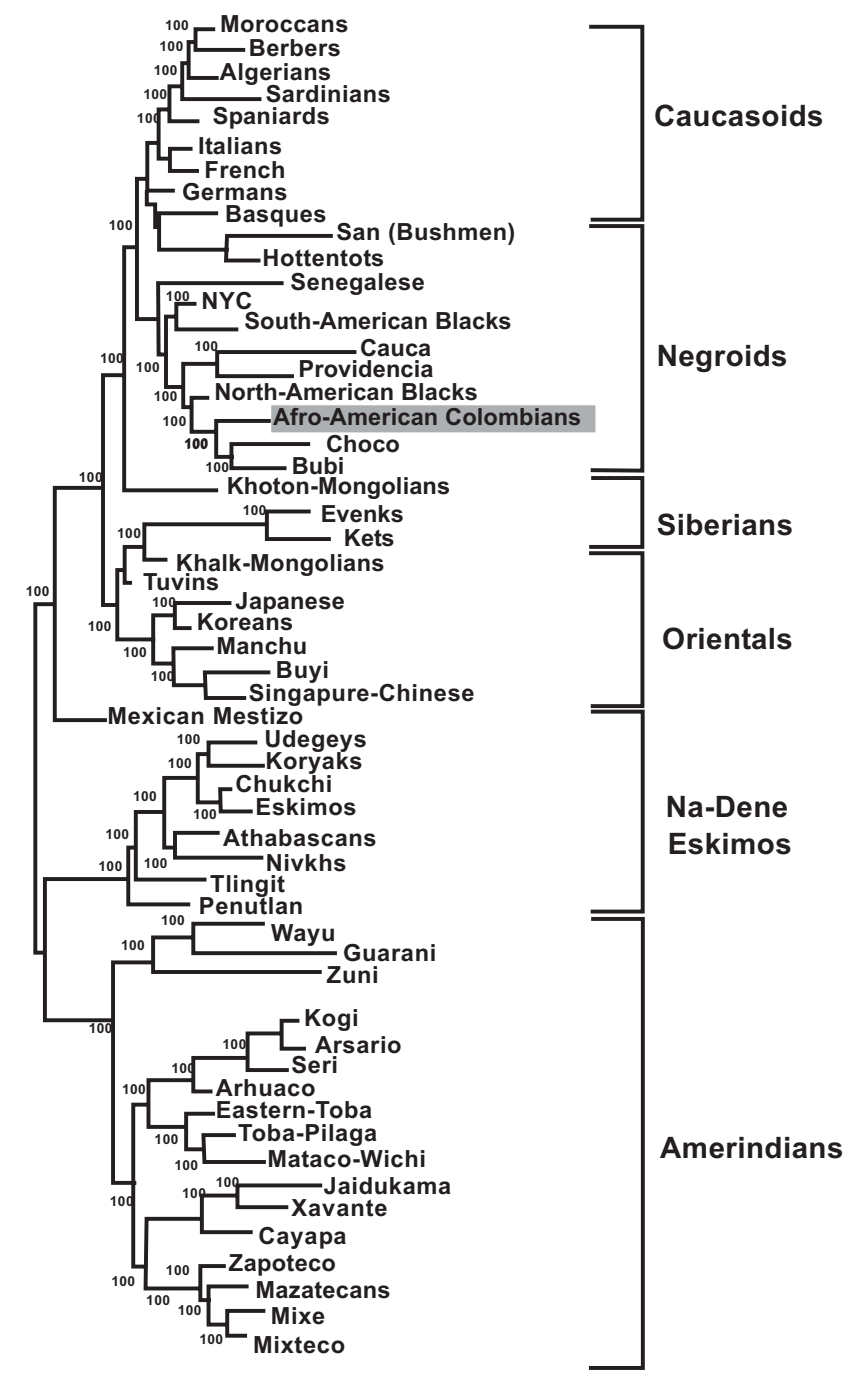

Fig. (2). Neighbour-Joining dendogram showing relatedness between Afro-American Colombians and other Afro-American groups, Africans, Caucasoids, Orientals and Amerindian populations. Genetic distances between populations (DA) were calculated by using high-resolution HLA-DRB1 genotyping. Data from other populations were taken from literature.
Mediterranean populations. However A68-B15 is frequently reported in sub-Saharan Black groups i.e., the Zulu and Bubi groups [10]. A68-B15 may represent a Negroid ancient haplotype. In addition, other uncommon DRB1-DQB1 linkage disequilibrium as DRB1*0302 DQB1*0402 has been reported in South African Blacks (HF: 18.5\%) [10], North American Blacks (HF: 7.1\%) [10], Afro-Americans from NYC (HF: 0.058\%) [9], Bubi from Bioko Island (HF: 2.5\%) [25]. It is a Negroid haplotype. Moreover, the haplotype DRB1*0804 - DQB1* 0301 found in our Afro-American Colombian sample is also reported in North American Blacks (HF: 5.8\%) [10], Afro-Americans from NYC (HF: $0.056 \%$ ) [9] and also found in a Zulu (South African) native tribe (Arnaiz-Villena A et al. unpublished results). This DR/DQ association will go in favour of being a specific Negroid haplotype, which may come from those ancient Bantu-African populations (founder effect).

\section{HLA -A -B -DRB1 -DQB1 Extended Haplotypes}

The ten most frequent extended haplotypes in our AfroAmerican Colombian group are shown in Table 3. There were four specific haplotypes from Afro-American Colombians (San Basilio de Palenque) showing high frequencies: 1) $\mathrm{A} * 02-\mathrm{B} * 07-\mathrm{DRB} 1 * 0801-\mathrm{DQB} 1 * 0301$, which is not found in other populations. However, in Caucasoid A2 -B7 goes with DR2 in Spaniards, Basques (also A2 -B7 -DR7) and Greeks and USA Caucasoids [10,26]; in addition, haplotype DRB1*0801-DQB1*0301 is present in French, Danish, Germans, and Italians, which suggests this new extended haplotype may have been generated after the admixture of two populations or two different haplotypes, breaking the normal Caucasoid association A2 -B7 -DR2; 2) A*68 -B*15 -DRB1*0102 -DQB1*0501 is not found in any other population, either. However, the A68 -B15 disequilibrium is present in Bubi and Nuba sub-Saharian tribes [33], and DRB1*0102 -DQB1*0501 is found in Negroid groups (see HLA DRB1-DQB1 associations); therefore, this new extended haplotype would be frequent in Negroid or AfroAmerican groups, and; 3) A*02 -B*35 -DRB1*1304 DQB $1 * 0301$ is not found to be complete, but it is partially present such as A2 -B35 -DR6 in Mexican Mestizo, Portuguese, Tlingit and North American Blacks [10]. In addition

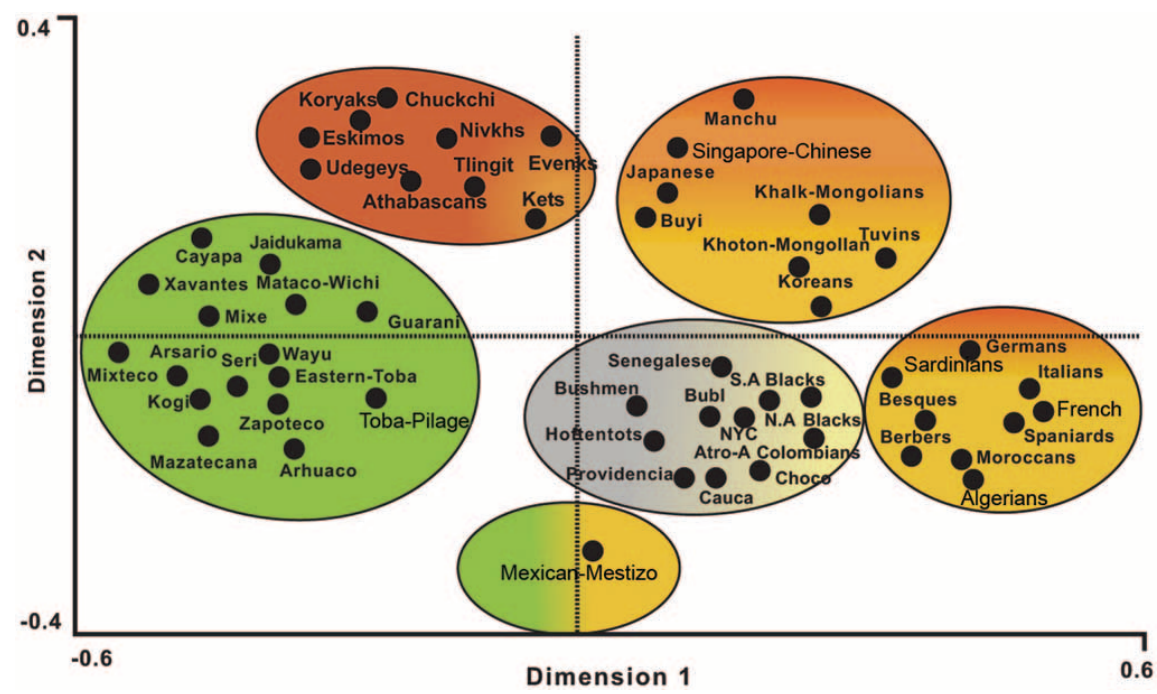

Fig. (3). Correspondence analysis showing a global view of the relationship among Negroid (brown), Amerindian (green), Siberian, Na-Dene and Eskimo (red), Asian (orange) and European/North African populations (yellow). 
Table 2. HLA-A-B, B-DRB1 and DRB1-DQB1 Two Loci Haplotypes with Linkage Disequilibrium in Afro-American Colombians

\begin{tabular}{|c|c|c|c|c|c|}
\hline Haplotype & HF & D' & Haplotype & HF & D' \\
\hline$A^{*}-B^{*}$ & & & DRB1*-DQB1* & & \\
\hline A1-B39 & 3.5 & $3.2^{\mathrm{b}}$ & 0102-0501 & 6.2 & $5.3^{\mathrm{c}}$ \\
\hline A2-B35 & 9.7 & $4.7^{\mathrm{a}}$ & 0301-0201 & 6.2 & $4.5^{\mathrm{b}}$ \\
\hline A2-B7 & 13.7 & $9.2^{\mathrm{c}}$ & 0302-0402 & 7.5 & $6.2^{\circ}$ \\
\hline A29-B57 & 2.5 & $2.3^{\mathrm{c}}$ & 0701-0201 & 7.5 & $5.8^{\mathrm{c}}$ \\
\hline A3-B58 & 3.7 & $3.3^{\mathrm{c}}$ & 0801-0402 & 7.5 & $5.0^{\mathrm{c}}$ \\
\hline A36-B53 & 3.7 & $2.3^{\mathrm{c}}$ & 0804-0301 & 6.2 & $5.0^{\circ}$ \\
\hline A68-B15 & 7.2 & $6.6^{\mathrm{b}}$ & $1001-0501$ & 3.7 & $3.2^{\mathrm{c}}$ \\
\hline A68-B51 & 7.2 & $5.0^{\mathrm{b}}$ & $1301-0603$ & 5.0 & $4.4^{\circ}$ \\
\hline A74-B50 & 3.7 & $2.2^{\mathrm{b}}$ & $1304-0301$ & 6.2 & $5.0^{\circ}$ \\
\hline B*-DRB1* & & & $1501-0602$ & 3.7 & $3.1^{\circ}$ \\
\hline B7-0801 & 4.5 & $5.0^{\mathrm{d}}$ & & & \\
\hline B15-0302 & 3.7 & $3.0^{\mathrm{c}}$ & & & \\
\hline B15-0804 & 6.2 & $5.0^{\mathrm{d}}$ & & & \\
\hline B35-1001 & 3.7 & $3.0^{\mathrm{b}}$ & & & \\
\hline B35-1304 & 5.0 & $3.9^{\mathrm{b}}$ & & & \\
\hline B51-0301 & 5.0 & $4.3^{\mathrm{b}}$ & & & \\
\hline
\end{tabular}

$\mathrm{HF}=$ Haplotype frequencies as percentage. D'= Linkage disequilibrium $\mathrm{x} 100$. OnIy haplotypes with significant linkage disequilibrium whose frequency is higher than $1 \%$ are listed. $\mathrm{a}=5 \times 10^{-2} ; \mathrm{b}=5 \times 10^{-3} ; \mathrm{c}=5 \times 10^{-4} ; \mathrm{d}=5 \times 10^{-5} ; \mathrm{e}=5 \times 10^{-6}$.

(Table 3), there are two haplotypes present in our AfroAmerican Colombian sample: A*36 -B*53 -DRB1*1104 DQB1*0502 and A*02 -B*07 -DRB1*1102 -DQB1*0301, which are present like A36 -B53 -DR11 and A2 -B7 -DR11 in North American Blacks and Brazilians, respectively [10]; 4) $\mathrm{A} * 01-\mathrm{B} * 51-\mathrm{DRB} 1 * 0301-\mathrm{DQB} 1 * 0201$; and 5) $\mathrm{A} * 02-$ B*15-DRB1*0302-DQB1*0402 (see Table 3).

\section{DISCUSSION}

Indeed, Afro-American groups have been characterised by a high HLA allele diversity as well as HLA class I-II associations have not been observed in other ethnic groups [9,24,26,30]. In general, HLA genetic distances between Black Africans and Mediterranean Caucasoids are short [34]. The number of studied individuals is considered sufficient for this very particular San Basilio de Palenque population $[2,3,6]$.

\section{A Strong West African Genetic Pool is at Present Main- tained in Afro-Americans}

It has been established that Blacks originally from Guinea Gulf had a large expansion across Central, East and South African regions on the year 400 AD $[7,46]$. The ma-

Table 3. Most Frequent HLA-A, -B, -DRB1 and-DQB1 Extended Haplotypes in the Afro-American Colombian Group Studied (San Basilio de Palenque). HF: Haplotype Frequency

\begin{tabular}{|l|c|l|}
\hline \multicolumn{1}{|c|}{ Haplotypes } & HF & \multicolumn{1}{|c|}{ Possible Origin } \\
\hline \hline $\mathrm{A} * 02-\mathrm{B} * 07-\mathrm{DRB} 1 * 0801-\mathrm{DQB} 1 * 0301^{\mathrm{a}}$ & 10.6 & Afro-American Colombian + \\
$\mathrm{A} * 02-\mathrm{B} * 35-\mathrm{DRB} 1 * 1304-\mathrm{DQB} 1 * 0301^{\mathrm{b}}[6,35-37]$ & 8.4 & Afro-American Colombian + \\
$\mathrm{A} * 68-\mathrm{B} * 15-\mathrm{DRB} 1 * 0804-\mathrm{DQB} 1 * 0301^{\mathrm{c}}[38-40]$ & 6.4 & Old sub-Saharian \\
$\mathrm{A}^{*} 02-\mathrm{B} * 15-\mathrm{DRB} 1 * 0302-\mathrm{DQB} 1 * 0402^{\mathrm{d}}$ & 5.0 & Afro-American Colombian + \\
$\mathrm{A} * 02-\mathrm{B} * 07-\mathrm{DRB} 1 * 1102-\mathrm{DQB} 1 * 0301^{\mathrm{e}}[41]$ & 4.2 & South American Blacks \\
$\mathrm{A} * 01-\mathrm{B} * 51-\mathrm{DRB} 1 * 0301-\mathrm{DQB} 1 * 0201^{\mathrm{f}}$ & 4.2 & Afro-American Colombian + \\
$\mathrm{A} * 68-\mathrm{B} * 15-\mathrm{DRB} 1 * 0102-\mathrm{DQB} 1 * 0501^{\mathrm{g}}[42]$ & 2.6 & Afro-American Colombian + \\
$\mathrm{A} * 03-\mathrm{B} * 58-\mathrm{DRB} 1 * 0102-\mathrm{DQB} 1 * 0501^{\mathrm{h}}[43]$ & 2.3 & Afro-American Black \\
$\mathrm{A} * 36-\mathrm{B} * 53-\mathrm{DRB} 1 * 1104-\mathrm{DQB} 1 * 0502^{\mathrm{i}}[44]$ & 2.3 & Afro-American \\
$\mathrm{A} * 03-\mathrm{B} * 07-\mathrm{DRB} 1 * 1501-\mathrm{DQB} 1 * 0602^{\mathrm{j}}[45]$ & 1.5 & Caucasoid \\
\hline
\end{tabular}

HF, haplotype frequency. References: [6,35-45]. + From our studied San Basilio de Palenque population.

${ }^{a}$ Not found in any other population, possibly it is Afro-American Colombian.

${ }^{\mathrm{b}}$ Found like A2-B35-DR6 in Colombian Mestizo (1.9\%), Portuguese (1.0\%), Tlingit and North American Black (1.1\%).

${ }^{\mathrm{c}}$ This haplotype would be old sub-Saharian haplotype (1.3\%) because parts of it A*68-B*15 and DRB $1 * 0804-\mathrm{DQB} 1 * 0301$ are common in sub-Saharian tribes.

${ }^{\mathrm{d}}$ Not found in any other population.

${ }^{\mathrm{e}}$ Found in Brazilian Blacks, like A2-B7-DR11.

${ }^{\mathrm{f}}$ Not found in any other population.

${ }^{\mathrm{g}}$ Not found in any other population, possibly Afro-Americans $(2.2 \%)$.

${ }^{\mathrm{h}}$ Also in Cameroon Yaounde Blacks, because partial A*03-B*58 (1.1\%) and DRB1*0102-DQB1*0501 (4.8\%) haplotypes are found in this population.

${ }^{\mathrm{i}}$ Found in North American Blacks like A36-B53-DR11.

${ }^{\mathrm{j}}$ Found in Northern Europeans such as Portuguese (1.3\%) and Irish (4.9\%), Brazilian (1.7\%) and Algerians (8.9\%). 
jority of these dispersed Bantú speaking tribes (Niger-Congo Phylum) took the sub-Saharan area and eliminated a large number of other tribes. Pygmies were pushed to central Africa woods and imposed a Bantu language. San (Bushmen) groups were reduced to the South West corner of African continent (Namibia), together with Hottentots, (an admixture of San and Bantu peoples) [46]. Nowadays, we can find several alleles and haplotypes present in various African populations (Nuba, Bubi, Zulu) [10,11,25] both in South and North Americans Blacks. Some West African classical alleles as A30, B42, are present in Bubi [25], Zulu [29], Colombian Blacks (from Pacific coast) [31] and Senegalese [47] but absent in our San Basilio de Palenque AfroAmerican group; it could have been missed because of genetic drift or during possible new HLA class I-II alleles/haplotypes formation in America [48]. In addition, the comparative analysis shows that North and South AfroAmerican groups have a similar HLA genetic profile. They cluster together in trees and have a short genetic distance between themselves (Fig. 2); this supports a common West African origin for these populations. Senegalese and Bubi from Bioko Island (Bantu) cluster together with North and South Afro-Americans [22]. Figs. (2, 3), show that San Basilio de Palenque group is also close to North American Blacks. They are sharply separated from Amerindian populations showing that limited gene flow has occurred from them (Figs. 2, 3). Hottentots and San (Bushmen) cluster in Fig. (2) with Mediterranean Caucasoids; the first population represents an admixture of Bantu and San people living in South Africa; San (Bushmen) represents being far related to Bantu population $[7,46]$. Correspondence analysis (Fig. 3) does confirm these results.

\section{Relationships Among Afro-Americans and American Natives Tribes}

Although people from Africa were established in America, being closely placed to Amerindians and they worked and lived together for almost five centuries, the Amerindian genetic flow to Black populations is lower or non-extant according to our data. There is a low frequency of classical HLA Amerindian alleles in Afro-American peoples $[9,23,24,26]$. In this study, three typical Amerindian alleles, DRB $1 * 0403$, DRB $1 * 0411$ and DRB1*1602 were present with very low frequency in Afro-Americans. This is concordant with previous studies, which found very low genetic admixture between Amerindian and Afro-American Colombian people [49].

\section{HLA Extended Haplotypes in Afro-American Colombi- ans: Recombination and Founder Effect}

HLA gene profile of our Afro-American Colombians sample has shown new haplotypes possibly generated in America by admixture of closely related African populations $[10,11,48]$. The classical A2 -B7 -DR2 present in Spaniards, Basques, Greeks and USA Caucasoids $[10,26]$ was found as A*02 -B*07 -DRB1*0801-DQB1*0301 in the sample studied (without DR2). Haplotypes such as A3 -B7 -DRB1*1501 -DQB1*0602, found in Algerians HLA study [6], also present in Mediterraneans [6] and now found in Afro-American Colombians could represent a founder effect of an HLA haplotype originated in Black Africa. It has established that during $12^{\text {th }}$ to $14^{\text {th }}$ centuries, an important flow of people occurred from North to West African region (also across Niger River) by trade activity (see Magreb History, http://www.britannica.com//)[46]. Also, Almoravides and Tuareg invasions as well as wars and conquest of Magreb region may have originated a possible admixture of various Mediterranean and Negroid groups, whose descents were later taken to America. Bantu expansion $[7,46]$ also went northwards $[7,46]$ and Negroid HLA alleles were found in North African Caucasoid populations [6,34]. In summary, this work suggests possible forces implicated in selection/creation of haplotypes in Afro-American groups and the minimal gene flow received from Amerindian neighbouring' populations.

Finally, these results could be relevant in bone marrow and other organs transplantation programs and for HLA and disease specific epidemiology studies [50].

\section{ACKNOWLEDGEMENTS}

This work was supported in part by grants from the Spanish Ministry of Health (FISS PI051039 and PI080838), Spanish Ministry of Foreign Affairs (A/9134/07 and A/17727/08) and three different Mutua Madrileña Automovilista grants.

We are grateful to Colombian Afro-American community of San Basilio de Palenque.

\section{REFERENCES}

[1] Imanishi T, Akaza T, Kimura A, Tokunaga K, Gojobori T. In: Tsuji K, Aizawa M, Sasazuki T, Eds. Genetic relationships among various human populations indicated by MHC polymorphisms. HLA 1991. Oxford, Oxford University Press 1992; pp. 627-32.

[2] Martinez-Laso J, de Juan D, Martinez-Quiles N, Gomez-Casado E, Cuadrado E, Arnaiz-Villena A. The contribution of the HLA-A, -B, $-C$ and $-D R,-D Q$ DNA typing to the study of the origins of Spaniards and Basques. Tissue Antigens 1995; 45: 237-45.

[3] Arnaiz-Villena A, Iliakis, P, Gonzalez-Hevilla, M, et al. The origin of Cretan populations as determined by characterization of HLA alleles. Tissue Antigens 1999; 53: 213-26.

[4] Mundial A. Santiago de Chile: Televisa, ed. 2008.

[5] Gutierrez I. Historia del negro de Colombia. Bogota 1986.

[6] Arnaiz-Villena A, Benmamar D, Alvarez M, et al. HLA allele and haplotype frequencies in Algerians. Relatedness to Spaniards and Basques. Hum Immunol 1995; 43: 259-68.

[7] McEvedy C, Jones R. Atlas of World Population History. Harmondsworth 1978 .

[8] Arrázola R. Palenque: Primer pueblo libre de América. Historia de las sublevaciones de los esclavos de Cartagena. Cartagena de Indias: Ediciones Hernández, Ed. 1970.

[9] Just JJ, King MC, Thomson G, Klitz W. African-American HLA class II allele and haplotype diversity. Tissue Antigens 1997; 49: 547-55.

[10] Imanishi T, Akaza T, Kimura A, Tokunaga K, Gojobori T. In: Tsuji $\mathrm{K}$, Aizawa M, Sasazuki T, Eds. Allele and haplotype frequencies for HLA and complement loci in various ethnic groups. HLA 1991. Oxford, Oxford University Press 1992; 1065-220.

[11] Clayton J, Lonjou C. Allele and haplotype frequencies for HLA loci in various ethnic groups. In: Charron D, Ed. Genetic diversity of HLA. Functional and medical implications. Paris, EDK 1997; pp. 665-820.

[12] Dielk M. La Negación en Palenquero. Análisis Sincrónico, Estudio Comparativo y Consecuencias Teóricas. Madrid: Iberoamericana, ed. 2000.

[13] Cuellar-Ambrosi F, Mondragon M, Figueroa M, Ruiz-Linares A. Sickle cell anemia and beta-globin gene cluster haplotypes in Colombia. Hemoglobin 2000; 24: 221-5.

[14] Arnaiz-Villena A, Timon M, Corell A, Perez-Aciego P, MartinVilla JM, Regueiro JR. Brief report: primary immunodeficiency caused by mutations in the gene encoding the CD3-gamma subunit of the T-lymphocyte receptor. N Engl J Med 1992; 327: 529-33. 
[15] Schneider S, Roessli D, Excoffier L. ARLEQUIN: a software for population genetics database analysis. [2.0]. Genetics and Biometry Laboratories, Department of Anthropology, University of Geneva 2000.

[16] Imanishi T, Akaza T, Kimura A, Tokunaga K, Gojobori T. In: Tsuji K, Aizawa M, Sasazuki T, Eds. Estimation of allele and haplotype frequencies for HLA and complement loci. HLA 1991. Oxford, Oxford University Press 1992; pp. 76-9.

[17] Arnaiz-Villena A, Martinez-Laso J, Gomez-Casado E, et al. Relatedness among Basques, Portuguese, Spaniards, and Algerians studied by HLA allelic frequencies and haplotypes. Immunogenetics 1997; 47: 37-43.

[18] Saitou N, Nei M. The neighbor-joining method: a new method for reconstructing phylogenetic trees. Mol Biol Evol 1987; 4: 406-25.

[19] Nei M. Genetic distances between populations. Am Nat 1972; 106 : 283.

[20] Nei M. Analysis of gene diversity in subdivided populations. Proc Natl Acad Sci USA 1973; 70: 3321-3.

[21] Nei M, Tajima F, Tateno Y. Accuracy of estimated phylogenetic trees from molecular data. II. Gene frequency data. J Mol Evol 1983; 19: 153-70.

[22] Young FW, Bann CM. A visual statistics system. In: Stine RA, Fox J, Eds. Statistical Computing Environments for Social Researches. London, Sage Publications 1996; pp. 207-36.

[23] Caraballo LR, Marrugo CJ, Erlich H, Pastorizo EM. HLA alleles in the population of Cartagena (Colombia). Tissue Antigens 1992; 39: 128-33.

[24] Trachtenberg EA, Keyeux G, Bernal J, Noble JA, Erlich H. Results of expedicion humana II. Analysis of HLA class II alleles in three African American populations from Colombia using the PCR/SSOP: identification of a novel DQB1*02 $(* 0203)$ allele. Tissue Antigens 1996; 48: 192-8.

[25] de Pablo R, Garcia-Pacheco JM, Vilches C, et al. HLA class I and class II allele distribution in the Bubi population from the island of Bioko (Equatorial Guinea). Tissue Antigens 1997; 50: 593-601.

[26] Motomi M, Beatty PG, Graves M, Boucher KM, Milford EL. HLA gene and haplotype frequencies in the North American population. The National Marrow Donor Program Registry. Transplantation 1997; 64: 1017-27.

[27] Hammond MG, Du Toit ED, Sanchez-Mazas A. HLA in subSaharan Africa: 12th International Histocompatibility Workshop SSAF report. In: Charron D, Ed. Genetic diversity of HLA. Functional and Medical Implications. Paris, EDK 1997; pp. 345-52.

[28] Dard P, Sanchez-Mazas A, Tiercy JM, et al. In: Tsuji K, Aizawa M, Sasazuki T, Eds. HLA-A, -B, and DR differentiation among North and West African populations. HLA 1991. Oxford University Press 1992; vol. 1: pp. 632-6.

[29] Hammond MG, Du Toit ED, Sachs JA, Kaplan C, Mbayo K. HLA in southern African populations. In: Tsuji K, Aizawa M, Sasazuki T, Eds. HLA 1991.Vol 1, Oxford University Press 1992; 636-8.

[30] Stastny P, Kalil J. In: Tsuji K, Aizawa M, Sasazuki T, Eds. HLA in North American and South American Negroids. HLA 1991.Vol 1, Oxford University Press, 1992; pp. 638-40.

[31] Blank M, Blank A, King S, et al. Distribution of HLA and haplotypes of Colombian and Jamaican black populations. Tissue Antigens 1995; 45: 111-6.

[32] Hill AV, Elvin J, Willis AC, et al. Molecular analysis of the association of HLA-B53 and resistance to severe malaria. Nature 1992; 360: 434-9.

[33] Fleischhauer K, Agostino A, Zino E, et al. Molecular characterization of HLA class I in Colombians carrying HLA-A2: high allelic diversity and frequency of heterozygotes at the HLA-B locus. Tissue Antigens 1999; 53: 519-26.
[34] Hors J, El Chenawi F, Djouhla S. HLA in North African population. 12th International Histocompatibility Workshop NAFR report. In: Charron D, Ed. Genetic Diversity of HLA. Functional and Medical Implications. Paris, EDK 1997; pp. 328-33.

[35] Leal CA, Mendoza-Carrera F, Rivas F, Rodriguez-Reynoso S, Portilla-de Buen E. HLA-A and HLA-B allele frequencies in a mestizo population from Guadalajara, Mexico, determined by sequence-based typing. Tissue Antigens 2005; 66: 666-73.

[36] Spinola H, Brehm, A, Williams F, Jesus J, Middleton D. Distribution of HLA alleles in Portugal and Cabo Verde. Relationships with the slave trade route. Ann Hum Genet 2002; 66: 285-96.

[37] Cao K, Hollenbach J, Shi X, Shi W, Chopek M, Fernandez-Vina MA. Analysis of the frequencies of HLA-A, B, and C alleles and haplotypes in the five major ethnic groups of the United States reveals high levels of diversity in these loci and contrasting distribution patterns in these populations. Hum Immunol 2001; 62: 100930 .

[38] Cao K, Moormann AM, Lyke KE, et al. Differentiation between African populations is evidenced by the diversity of alleles and haplotypes of HLA class I loci. Tissue Antigens 2004; 63: 293-325.

[39] Ellis JM, Mack SJ, Leke RF, Quakyi I, Johnson AH, Hurley CK. Diversity is demonstrated in class I HLA-A and HLA-B alleles in Cameroon, Africa: description of HLA-A*03012, *2612,*3006 and HLA-B*1403, *4016, *4703. Tissue Antigens 2000; 56: 291302 .

[40] Spinola H, Brehm A, Bettencourt B, Middleton D, Bruges-Armas J. HLA class I and II polymorphisms in Azores show different settlements in oriental and central islands. Tissue Antigens 2005; 66: 217-30.

[41] Middleton D, Williams F, Meenagh A, et al. Analysis of the distribution of HLA-A alleles in populations from five continents. Hum Immunol 2000; 61: 1048-52.

[42] Williams F, Meenagh A, Darke C, et al. Analysis of the distribution of HLA-B alleles in populations from five continents. Hum Immunol 2001; 62: 645-50.

[43] Williams F, Meenagh A, Maxwell AP, Middleton D. Allele resolution of HLA-A using oligonucleotide probes in a two-stage typing strategy. Tissue Antigens 1999; 54: 59-68.

[44] Middleton D, Williams F, Hamill MA, Meenagh A. Frequency of HLA-B alleles in a Caucasoid population determined by a twostage PCR-SSOP typing strategy. Hum Immunol 2000; 61: 128597.

[45] Ligeiro D, Fonseca JE, Abade O, et al. Influence of human leucocyte antigen-DRB1 on the susceptibility to rheumatoid arthritis and on the production of anti-cyclic citrullinated peptide antibodies in a Portuguese population. Ann Rheum Dis 2007; 66: 246-8.

[46] McEvedy C. The Penguin Atlas of African History, London 1980.

[47] Dieye A, Diaw ML, Rogier C, Trape JF, Sarthou JL. HLA-A, -B, $\mathrm{C}$, -DR, -DQ typing in a population group of Senegal: distribution of HLA antigens and HLA-DRB1*13 and DRB1*11 subtyping by PCR using sequence-specific primers (PCR-SSP). Tissue Antigens 1996; 47: 194-9.

[48] Degos L, Dausset J. Human migrations and linkage disequilibrium of HLA system. Immunogenetics 1974; 1: 195-210.

[49] Yunis JJ, Ossa H, Salazar M, et al. Major histocompatibility complex class II alleles and haplotypes and blood groups of four Amerindian tribes of northern Colombia. Hum Immunol 1994; 41: 24858.

[50] Silvera-Redondo C, Gomez-Casado E, Martinez-Laso J, et al. A new HLA-Cw allele (Cw*0808) found in a Colombian Mestizo individual possibly generated by an intralocus/interloci gene conversion. Immunogenetics 2000; 51: 1053-7.

This is an open access article licensed under the terms of the Creative Commons Attribution Non-Commercial License (http://creativecommons.org/licenses/by$\mathrm{nc} / 3.0 /$ ) which permits unrestricted, non-commercial use, distribution and reproduction in any medium, provided the work is properly cited. 